https://doi.org/10.31470/2706-7904-2020-15-250-254

\title{
ПСИХОЛІНГВІСТИКА РОЗВИТКУ ЧИТАННЯ ДІТЕЙ СТАРШОГО ДОШКІЛЬНОГО ВІКУ
}

Psycholinguistics of Reading Development in Older Preschool Children

\section{Iryna Tovkach}

Ph.D. in Psychology, Senior Lecturer

Borys Hrinchenko Kyiv University (Ukraine)

i.tovkach03@gmail.com

https://orcid.org/0000-0002-3848-3824

\begin{abstract}
The article reveals the problem of the development of reading in a child of older preschool age as a psycholinguistic phenomenon. Speaking about the development of reading in older preschool children in general, we consider reading not only as one of the important types of speech activity, but also as the child's ability to perceive, understand and realize the information read, which is printed (transmitted) in one way or another. using digital technologies. Also in the article we consider different thoughts of teachers, psychologists, linguists and other scientists about the problem of reading development in children. Summarizing them, it is necessary to give specialists and practitioners a clear idea of the process of reading by a child of older preschool age.
\end{abstract}

Key words: reading, psycholinguistics, development, older preschool children.

\section{Вступ \\ Introduction}

Вибір читання е якості основного комунікативного вміння зумовлений низкою причин, однією 3 яких є його освітня та соціокультурна значимість, яка полягає в розширенні знань i кругозору дітей старшого дошкільного віку. Дослідження психолінгвістів переконливо доводять необхідність глибокого вивчення понять «читання», «розвиток читання дітей старшого дошкільного віку», адже до недавнього часу відбувалося недооцінювання вивчення зазначених дефініцій.

Методи та методики дослідження Methods and Techniques of the Research

У процесі вивчення феноменів читання, розвиток читання дітей використовувалися такі теоретичні методи дослідження: аналіз психологічної i 
психолінгвістичної літератури, узагальнення й інтеграція отриманих результатів аналізу даних. Систематизація узагальнених даних теоретичної частини дослідження, висновування.

\section{Результати}

\section{Results}

У даних умовах вибір читання в якості основного комунікативного вміння зумовлений низкою причин, однією 3 яких $€$ його освітня та соціокультурна значимість, яка полягає в розширенні країнознавчих знань і кругозору дітей старшого дошкільного віку. У зв'язку з цим велике значення набуває пізнавальна функція читання, що в свою чергу передбачає розгляд читання не тільки як засобу пізнання культури, а й з точки зору функціонування психічних пізнавальних процесів i механізмів, що лежать в основі даного виду мовленнєвої діяльності.

Проблема визначення сутності читання, розвитку читання дитиною не є новою. Так у словнику В. Даля поняття читати розуміється як читати, розбирати письмо, грамоту, писане чи друкованими літерами (Даль, 1880-1882). Словник Б. Грінченка дає наступну інформацію: «Читання, -ня, с. (1) Чтеніе. Грин. I. 289. Яке співання, таке й читання. (2) Считаніе. У нас пінязьки без читаня - безъ счету (Грінченко, 1958: 483). Поняття «читання» в академічному тлумачному Словнику української мови у 11 томах подано у трьох значеннях: 1. Дія за значенням читати). Голосне читання; Літературне читання; Статарне читання. (2). Те, що читають, читаний текст. (3). мн. Цикл доповідей, лекцій, виступів читців, присвячений якому-небудь колу питань (1980: 337). Словник іншомовних слів дає визначення щодо курсорного читання як швидке прочитування тексту, без детального розгляду. Протилежне статарне читання. Б. Мещеряков, розкриваючи поняття «мовленнєва діяльність» (verbal behavion) як ту чи іншу форму внутрішнього вживання мови для вираження, передачі чи породження інформації, думок, почуттів пише, що в вузькому смислі М.д. - це діяльність в якій створення чи передача тексту виступає в якості основної мети. А самостійними видами чи компонентами М.д. виступають говоріння і письмо (активне мовлення), слухання і читання (пасивне мовлення), запам'ятовування i пригадування вербального матеріалу (Мещеряков, 2007: 231).

Отже, читання (пасивне мовлення) - це вид мовленнєвої діяльності, що має тісний зв'язок як $з$ вимовою, так і 3 розумінням мови. Розрізняють також самостійне й несамостійне читання дитиною. Самостійне дитяче читання - це індивідуальне мовчазне читання книги без допомоги дорослого (педагога чи іншого кваліфікованого читача). 
Процес читання був предметом дослідження науковців різних галузей, а саме: педагогів (Богуш, 2019; Вашуленко, 1982; Гербова, 1987; Горецький, 1985; Журова, 1978; Зайцев, 1997; Сохин, 1984; Сухомлинський, 1977; Тумакова, 1991; Ушинський, 1955 та ін.), психологів (Амонашвілі, 2013; Венгер, 2010; Выготский, 1983; Запорожец, 1986; Костюк, 1989; Эльконин, 1962; Леонтьев, 2005 та ін.); лінгвістів (Гвоздев, 1961; Кузьменко, 1980; Пентилюк 2015; Фомичова, 1981 та ін.); психолінгвістів (Зимняя, 2001; Калмикова, 2008, 2011, 2017; Леонтьев, 2005 та ін.). Так, К. Ушинський у своїй праці «Про початкове навчання грамоти взагалі» писав, що «свідоме» читання визначає результати й якість читання; що легшою $є$ метода навчання, яка пропонується дитині, то раніше можна почати навчання (Ушинський, 1983). В. Сухомлинський зазначав: «Процес письма й читання буде легким, якщо грамота стане для дітей яскравим, захоплюючим шматком життя, сповненим яскравими образами, звуками, мелодіями» (Сухомлинський, 1977: 78). Одним із мотивів розуміння, за Г. Костюком, є потреба розповісти іншим про щось, поділитися 3 ними своїми думками: описати, пояснити, довести, переказати, висловити судження про почуте, прочитане (Костюк, 1989). Л. Калмикова вважає, що дошкільник сприймає й розуміє не повідомлення в його мовному формальнограматичному оформленні, а за його допомогою бачить світ речей, явищ, дій, ознак, ситуацій дійсності. I в цьому йому допомагає смисл, виокремлений і відтворений ним зі сприйнятого висловлення (Калмикова, 2008). Тому, беручи книжку до рук, пропонуючи ऑiі розглянути та послухати, ми запрошуємо дитину дошкільного віку насамперед до спілкування за їі змістом і формуємо бажання навчитися читати самостійно. М. Зайцев читання розглядає не як передумову «прискореного розвитку», а як процес оволодіння новою мовною реальністю - письмовим мовленням (Зайцев, 1997). Г. Доман навчання дітей читання представляє як читання не за буквами $\mathrm{i}$ складами, а відразу словами, оскільки це доступніше і значно простіше для дітей будь-якого віку, починаючи з 6-8 місяців (Доман, 1995).

Загальні положення про значення читання дітьми дошкільного віку в сучасному освітньому процесі розглядають у роботах зарубіжні (Амонашвілі, 2013; Доман, 1995; Пол \& Руссо, 2020; Хірш-Пасек 2014 та ін.) та українські дослідники (Богуш, 2013, 2019; Вашуленко \& Скрипченко, 1982; Іваненко, 1987; Калмикова, 2008, 2011, 2017; Карабаєва, 2010 та ін.); про поетапне формування оперативних одиниць письма й читання (Корнев, 1997); про текст як об'єкт лінгвістичного дослідження (Гальперин, 1976, Чепелєва, 1992 та ін.); про розуміння як компонент психології читання (Брудный, 2001 та ін.); про суттєве значення пізнавальної активності в процесі читання (Выготский, 1983; Эльконин, 1962 та ін.). Аналіз наукових джерел засвідчив, що в психолінгвістиці феномен «розвиток 
читання дитиною» приваблював учених (Леонтьев, 2005; Эльконин, 1962; Журова, 1978 та ін.). Так, Д. Ельконін зазначав, що читання є відтворення звукової форми слова на підставі його графічного позначення (Эльконин, 1962). Внутрішній механізм читання представляє собою доволі складне явище 3 системою орієнтуванння i коригувань, перш за все зорових, мовленнєворухових, мовленнєвослухових, мисленнєвих й інших компонентів.

Дослідження психологів, психолінгвістів засвідчують про можливості дитини дошкільного віку не лише усвідомлювати окремі факти дійсності, але й пояснювати їх. Тому розвивати читання необхідно з малку в умовах сім’ї, не чекаючи поки дитина піде до школи. Так П. Пол та М. Руссо у своїй книзі «Як виховати читача» пишуть: «Школа - це місце, де дітей вчать, що вони мусять читати, а домівка - місце, де діти вчаться читати, бо самі цього хочуть. Саме вдома вони навчаються любові до читання...» (Пол \& Руссо, 2020: 10). I завдання дорослих - зробити читання задоволенням для дитини.

Отже, розуміємо читання дитиною старшого дошкільного віку не лише як один 3 найважливіших видів мовленнєвої діяльності, не тільки як засобу пізнання культури, а й 3 точки зору функціонування психічних пізнавальних процесів і механізмів, що лежать в основі даного виду мовленнєвої діяльності; як здатність дошкільника сприймати, розуміти й усвідомлювати інформацію, яка надрукована (передана) тим або іншим способом чи відтворена 3 допомогою цифрових технологій. Проте аналіз наукової літератури, крім виявлених проявів, дав змогу з'ясувати, що становлення процесу читання як вербального мовленнєво-мисленнєвого процесу на дошкільному етапі онтогенезу до цього часу в цілому залишається недостатньо вивченим.

\section{Висновки}

\section{Conclusions}

Таким чином, проблема недостатньої розробленості означеного феномену «розвиток читання дітей дошкільного віку» та недостачі програм психолінгвістичного розвитку дітей старшого дошкільного віку набуває важливого значення, адже найбільш суттєві зміни відбуваються саме у зазначеному віковому періоді, що $є$ перехідним між двома етапами розвитку, один з яких пов'язано з ігровою, а другий 3 навчальною діяльністю. Виділення читання як окремого явища серед різних мовленнєвих процесів має велике прикладне значення, особливо для лінгвометодики, адже дозволяє організовувати процес навчання читання дітей старшого дошкільного віку адресно, залежно від їх вікових та індивідуальних особливостей. 


\section{Література}

References

Зимняя, И.А. (2001). Лингвопсихология речевой деятельности. Москва: Московский психолого-социальный институт; Воронеж: НПО «МОДЭК».

Калмикова, Л.О. (2011). Психологія розвитку мовленнєвої діяльності дітей дошкільного віку. Автореф. дис. д-ра психол. наук. Київ.

Калмикова Л.О. (2008). Психологія формування мовленнєвої діяльності дітей дошкільного віку. (Монографія). Київ: Фенікс.

Калмикова, Л.О. (2017). Перспективність і наступність в навчанні мови й розвитку мовлення дітей дошкільного $і$ молодшого шкільного віку: психолінгівістичний $i$ лінгвістичний виміри. Київ: Видавничий Дім «Слово».

Корнев, А.Н. (1997). Нарушения чтения и письма у детей. Санкт-Петербург. МиМ.

Леонтьев, А.А. (2005). Основы психолингвистики (4-е изд.). Москва: Смысл.

Пол, П., \& Руссо, М. (2020). Як виховати читача. (Пер. $з$ анг О. Стукала). Київ. ArtHuss.

Чепелєва, Н.В. (1992). Психологія читання навчальної та наукової літератури в системі професійної підготовки студентів. Автореф. дис. д-ра психол. наук. Киъв: КДПІ ім. М.П. Драгоманова. 